\title{
The Queen of Propaganda: Boudica's Representation in Empire
}

\author{
Eleanor M. Vannan ${ }^{1}$ \\ eleanormvannan@gmail.com
}

\begin{abstract}
Boudica was an Iceni queen c. $60 \mathrm{CE}$ in Roman-occupied Britain who revolted against the Roman empire. While there is a scarcity of primary sources that document her life, Boudica has remained a dominant figure in conceptualisations of British national identity. This paper examines the works of the Roman historians, the archaeological record, and the depictions of Boudica in different periods and analyses the ability of historians to record events without being influenced by the ideology of their contemporary periods. Through a comparative examination of sources, this paper argues that Boudica should not be approached as a verifiable historical figure but as a tool to understand imperial propaganda.
\end{abstract}

Keywords: Boudica; Roman empire; British empire; imperial propaganda; classical reception

${ }^{1}$ I would like to thank my faculty mentor, Dr. Gregory Rowe for his enthusiastic encouragement and guidance, and my parents-in-law, Joe and Jean McDonald, for indulging my historical curiosity while I was in England and watching my son while I wrote this paper. 


\section{The Queen of Propaganda: Boudica's Representation in Empire}

A first century CE Celtic tribal queen who was defeated in battle seems an unlikely historical figure to be an icon of imperial power for two empires with more than a thousand years between them. Yet this is how Boudica, queen of the Iceni, was imagined by those who told the stories of the Roman and British empires. Rome and Britain, in their zeniths, dominated much of the known world. Being victors, Rome and Britain controlled the historical narratives of their day, and Boudica was used by both empires to promote a message that glorified both cultures. The Roman historians Cassius Dio and Tacitus centre Boudica in their accounts of Romano-Britain in $61 \mathrm{CE}$. Both writers have been given a principal place in the canon of Romano-British history and the history of the British empire. In the $19^{\text {th }}$ century CE, Boudica re-emerged as an icon of nationalism in the British empire and flourished as an icon of British exceptionalism during Queen Victoria's reign. The $19^{\text {th }}$ century portrayals of Boudica draw from Roman sources and have persisted into the $21^{\text {st }}$ century, as many fifty pence coins attest. The default approach to the study of Boudica has been consumed by attempts to know her as a verifiable historical figure. These attempts are inherently troublesome. Roman historical sources are the only primary sources that mention Boudica, and archaeological evidence is scarce. The Roman sources must not be read at face value, as they are products that promote the superiority of Roman culture. They must be read with a great deal of circumspection. The same can be said for $19^{\text {th }}$ century descriptions and depictions of Boudica. Scholars like Martha Vandrei (2018) and Margaret Steyn (2019) have worked to revise Boudica's historical narrative and explore her broader impact. These works are complicated by the current climate of historiography's politicization and are often challenged on ideological grounds. Boudica and her people are better understood through a comparative examination of the Romano-British archeological record, legal texts, and representations in works of art. What emerges from this investigation is not only a more historically accurate account, but an altogether fascinating understanding of how two empires manipulated history to serve their programs of imperial propaganda.

\section{Defining Ideology and Propaganda and the Current Climate of Historiography}

To understand the treatment of Boudica in the primary historical literature and the use of Boudica as a nationalist symbol in subsequent periods, it is necessary to develop theories about how ideologies and propaganda function. Currently, there is a movement to frame historical revision pejoratively. David Abulaf (2021), a professor of Mediterranean history at the University of Cambridge, recently published "We Can Never Surrender to the Woke Witchhunt Against Our Island Story" as an editorial for the Daily Mail. Abulaf writes ardently against "today's woke zealots" and charges them with exploiting "history as an instrument of propaganda" (para. 3). Abulaf acknowledges that historical figures are often more complex than their popular representations; what he omits is the long connection between propaganda and how histories are told. This paper seeks to examine the telling of Boudica's story in the context of ideologies of nationalist history.

In "On the Ubiquity of Ideology in Modern Societies," Masters (1979) describes the proliferation of ideology as a modern phenomenon spurred on by the rise of secularism. Masters 
claims ideology to be a re-centering of an individual's world view around the political, which did not occur on a mass scale until after the Second World War. Masters is correct in stating that ideology did not rise to the level of conscious discussion until the $20^{\text {th }}$ century. However, defining ideology's foundational elements shows a longer presence in human history. Seliger (2019) states that ideology has two facets - fundamental ideology and operative ideology. Fundamental ideology is simply the foundational assumptions an individual makes. These foundational assumptions include beliefs about human nature, concepts of the self, and ethical principles. Operative ideology is the translation of those foundational assumptions into policies and actions. An ideology is merely a system of ideas that provides an ordering principle (Seliger, 2019). The idea that ideology is a modern phenomenon mistakes ideology's expression in one period for ideology's definition. However, this mistake clarifies that one's ideology is intrinsically linked to the contemporary period in which one lives. Thus, disinterested historians cannot escape creating work in the context of their ideological perspectives (Mccullagh, 2000)

The disinterested historian is a modern construct. Before the modern period, historians were often quite open about their biases (Breisach, 2007). Historians' ideological biases have, at times, moved towards propaganda. Harrod Lasswell (1927) defines propaganda as the "the management of collective attitudes by the manipulation of significant symbols" (p. 627). This process is never explicit. Rather, the shared cultural connotations of symbols allow the individual to make inferences. Extended exposure to propaganda moulds the ideology of the individual until it conforms to the ideology of the state. Once it is made explicit, propaganda ceases to adhere to the individual's self-image. Propaganda reveals the identities and motivations of power (Lasswell, 1927). Lasswell (1927) takes a top-down approach to propaganda, in which those with authority instruct the masses. Herman and Chomsky (1988) approach propaganda by examining mechanisms. They claim propaganda to be a tool to create a consensus of public opinion that grants consent to those in power. The structure to manufacture this consent requires an infrastructure to disseminate propaganda, which will have economic interests separate from the interests of political elites. Further, as this model of propaganda seeks to create a consensus of public opinion, the masses are manipulated to integrate themselves into a propagandistic narrative, and, having adjusted their ideologies, further perpetuate a propagandistic program (Herman \& Chomsky, 1988). Like ideology, propaganda was not explicitly studied until the $20^{\text {th }}$ century, but the fundamental elements, as defined by Lasswell and Herman and Chomsky, are present throughout history (Taylor, 1995).

\section{The History of Britain and Boudica According to the Written Roman Records}

Roman historians were the first to write an historical account of Boudica. No doubt her story was told by her people, but since written history is privileged, Roman primary sources have been given legitimacy. The medium itself functions to support a propagandistic narrative. The Roman authors use literary tropes to describe Britain and its inhabitants as mysterious and harsh. In the Apocolocyntosis, Seneca (ca.54 C.E./2014) writes that Britain is "beyond the sea-shores which one sees" (p. 473). Horace (ca. 23 B.C.E./2003) writes of, "The earth's far-off Britons" (Poem 35, line 33) and refers to them as the "fierce, inhospitable Britons" (Poem 4, line 30.) The Romans are clear that Britons are barbarians. The official Roman history for Britain begins with the first invasion of Britain, in the winter of 55 BCE (Caesar, ca. 54-49 B.C.E./1917). Caesar spent the year campaigning against the Gauls in what is now France and Belgium. Caesar (ca. 54-49/ 
1917) received reports that the Gauls were receiving aid from the inhabitants of the British Isles. In The Gallic Wars, Caesar writes that the motivation for the first invasion was to gain a better understanding of the inhabitants and the extent of military aid they could provide to the Gallic tribes. After the return of Caius Volusenus from a small scouting mission, Caesar launched an invasion of Britain with two legions. Caesar writes that the barbarian inhabitants, not being used to the sight of large warships, rallied chariots and soldiers for battle. The Roman forces underperformed but eventually overpowered the Britons. Having secured a peace, Caesar returned to continental Europe and planned another invasion for the summer of 54 BCE. Lacking geographical knowledge of Britain was a significant disadvantage for Caesar's second invasion. However, the Romans' superior military skill lead Caesar's forces to overcome the Britons. Caesar was able to install a series of client kings who were loyal to Rome.

Caesar ca. 54-49 B.C.E./1917) states that the population of the Britons was large with agricultural practices similar to the Gauls but sees little cultural development beyond this. While Caesar describes a degree of variation between native tribes, according to him, all Britons were barbarous. Similarly, the Romans found the native cultural customs to be barbaric. Caesar describes the natives' personal hygiene and grooming practices as primitive. Further, Caesar is disturbed by the sexual mores. He states that the native women are not sexually monogamous. The ideological importance of paternity to the Romans cannot be overstated (Gunderson, 2009). Caesar states that the father of a native child is assumed to be whichever man took a woman's virginity. Caesar considers this practice to be a preeminent sign of barbarism (Webster, 1980).

Britain's distinct cultural practices fascinated ambitious Romans as they saw the potential for the glory of conquest. Cicero (ca. 50-43 B.C.E./2002) writes to his brother Quintus, who was stationed with Caesar in Britain, "All you have to do is to give me Britain to paint. I'll use your colours with my brush" (p. 133). Still, Rome was satisfied with the status of Britain as a series of client kingdoms. The remoteness of Britain hindered their ability to administrate Britain as a fully integrated Roman province. In Book IV of the Geography, Strabo (ca. 7 B.C.E-23 C.E./2014) states that the system of client kingdoms has "managed to make the whole of the island virtually Roman property" (pp. 257-259). Strabo continues with an explanation for Rome being satisfied with the status of the client kingdoms:

they submit so easily to heavy duties, both on the exports $[\ldots]$ and on the imports $[\ldots]$ that the expense of the army would offset the tribute-money [...] and, [...] dangers be encountered, if force is applied. (p. 259)

In $43 \mathrm{CE}$, the Emperor Claudius annexed Britain, officially making it a Roman province. Britain's political climate became increasingly volatile with uprisings from British tribes. Cassius Dio (ca. 230-235 C.E./1925) writes,

Aulus Plautius, [...] made a campaign against Britain; for a certain Bericus, who had been driven out of the island as a result of an uprising, had persuaded Claudius to send a force thither. Thus, it came about that Plautius undertook this campaign. (60.18)

Roman governors oversaw the newly annexed Britain; their presence there created an immediate authority that outranked the client kings. This presence oppressively interfered with the native inhabitants' affairs. During the governorship of Gaius Suetonius Paulinus (Suetonius Paulinus) in $61 \mathrm{CE}$, a group of Britons revolted (Dio, ca. 230-235 C.E./1925). The central figure in the revolt of $61 \mathrm{CE}$ was the Iceni queen, Boudica, who was catalyzed into action by the death of the Iceni king, Prasutagus (Tacitus, ca. 56-120 C.E./2014). In Book XIV of the Annals, Tacitus (ca. 56-120 C.E./2014) writes, 
The Icenian king Prasutagus, celebrated for his long prosperity, had named the emperor his heir, together with his two daughters; an act of deference which he thought would place his kingdom and household beyond the risk of injury. The result was contrary - so much so that his kingdom was pillaged by centurions, his household by slaves; as though they had been prizes of war. As a beginning, his wife Boudicca was subjected to the lash and his daughters violated: all the chief men of the Icenians were stripped of their family estates, and the relatives of the king were treated as slaves. (14.31)

The Roman treatment of the nobles caused anxiety amongst the Britons. Tacitus (ca. 56-120 C.E./2014) writes,

Impelled by this outrage and the dread of worse to come-for they had now been reduced to the status of a province - they flew to arms, and incited to rebellion the Trinobantes and others, who, not yet broken by servitude, had entered into a secret and treasonable compact to resume their independence. (14.31)

Suetonius Paulinus was campaigning in Wales when revolting Britons destroyed Camulodunum, Londinium, and Verulamium. Boudica's success was short-lived (Tacitus, ca. 5612- C.E./2014). Suetonius gathered the remaining legions and met the Britons in battle. The Romans were victorious as Tacitus (ca. 56-120 C.E./2014) writes,

The glory won in the course of the day was remarkable, and equal to that of our older victories: for, by some accounts, little less than eighty thousand Britons fell, at a cost of some four hundred Romans killed and a not much greater number of wounded. Boudicca ended her days by poison. (14.37)

The revolt of $61 \mathrm{CE}$ was only of moderate significance to the Romans. Boudica's revolt was just one of many stories they Romans told to show their power and authority (Webster, 1999). Imperial administration grew arduous as the empire's territory expanded. Yet, Rome did not question their capacity for military power. Their victory against the natives was always presumed; the key value in recounting these events to later citizens was as a cautionary tale about being caught unprepared (Webster, 1999).

\section{Impeaching the Privileged Written Histories Through the Archeological Record}

Tacitus and Dio present their accounts as historical fact, and in isolation they appear credible. One of the great virtues of Rome's written records is the ubiquity of teleological justifications for actions and events. Depictions of conquered people frequently informed these explanations. However, authors in the empire were often faulty narrators. It seems unlikely that accounts of Boudica's revolt would have historicity if the Britons as a culture were inaccurately represented. Discrepancies exist between Roman sources and the archeological record; examining non-written primary sources shows the Romans misunderstood the British natives from first contact. Comparing other forms of evidence impeaches the privileged written accounts and shows the need for a critical reading of the written word. Caesar makes a connection between the continental Gauls and coastal Britons. Other Roman authors, most notably Strabo (ca. 7 B.C.E.23 C.E./1917), claim that the Britons had little external contact beyond that. Claims of an isolated pre-Roman Britain are demonstrably false. Parts of Britain are rich in deposits of copper and tinessential metals in Bronze Age technologies. From the Bronze Age on, the inhabitants of Britain exploited the richness of their natural resources using sophisticated practices (Williams \& de 
Veslud, 2019). Williams and de Velsud (2019) analyzed the composition of copper from the Great Orme mine in Wales and found this form of copper was extracted and distributed as far as the Baltic region. They write that "[this distribution] suggests that there were active, long-distance exchange networks in place" (p. 1188). The archeological record contradicts the classical perception of Britain's isolation in the evidence for Bronze Age trade between the isles and the continent. Exaggerating a people's isolation and primitiveness in imperial histories is a propagandistic principle to justify colonial expansion (Rohland et al., 2021).

Britain's connection to continental Europe continued into the Iron Age. Artifacts of material culture are often examined for uniqueness. If material culture is stylistically distinct from surrounding cultures, it is termed to be an insular art style (Joy, 2015). The lack of cultural exchange is thought to be an indication that there was limited or no contact between cultures. The insular art style of Iron Age Briton is said to be proof that there was scarce contact with continental Europe prior to Roman contact. However, the acceptance of insular art as proof of cultural isolation is debated. In "Connections and Separation? Narratives of Iron Age Art in Britain," Jody Joy (2015) states that insular art styles also occur when a deliberate attempt is made to distinguish one culture from another. Insular art occurs both in isolation and through deliberate attempts to resist cultural amalgamation. Thus, the presence of insular art cannot indicate the degree of cross-cultural connections independent of other archeological proof. The archeological record for Iron Age Britain contains Mediterranean objects and art that fuses Britain's insular style with continental art (Joy, 2015). Joy suggests that these finds weaken the claim that Iron Age Britain was insular. Instead, Joy argues the diversity of objects of material culture indicates a desire to preserve the native culture (Joy, 2015). Rome ideologically divided cultures between barbarians and citizens of the city. There was little propaganda value in emphasizing contact between distinct barbarian cultures. Further, the dominant power was ideologically dubious towards a barbarian people valuing their cultural heritage. It was more manageable to assume the natives lacked the opportunity to be civilized as they were uncontacted (Gonzalez \& Gugliemi, 2017).

Rome did claim that the Britons staunchly defended their cultural identity. However, the Romans claimed this as a justification for administrative difficulties in the region (Webster, 1999). As is common in propaganda, there is more nuance to the Briton's cultural identity in this period; Rome omitted the degree to which British inhabitants happily assimilated into Roman culture. In An Imperial Possession, David Mattingly (2006) cautions that most of the archeological artifacts discovered come from the curial class of Romano-Britons. Nevertheless, the objects found show that "they used Roman material culture as a means of enchaining their own prestige within British society" (p. 283). The Britons did not just assimilate into the Roman cultural identity. Britons morphed their culture by incorporating Roman principles (Mattingly, 2006). Dominic Perring (2002) writes in The Roman House in Britain that an architectural shift in Britain's houses occurred rapidly, adapting to the changing social practices of the new Romano-British identity. The cultural shift also occurs in the religious practices of Romano-Britain. In Roman Britain, David Shotter (2005) writes that representations of Celtic deities became stylistically Roman. Further, Shotter states that the practice of interpretatio Romana paired Roman gods with their Celtic equivalent, forming new Romano-British gods.

Before annexation, the Britons were Romanizing. The Cunobelin coin with Latin inscription c.10-40 AD housed in the British Museum is an example of British elites adopting Latin words as a symbol of their authority. Coins were used in Britain by the mid-late secondcentury BCE. The designs of coins were iconographic statements of power (Creighton, 2002). 
Creighton (2002) states the imagery on British coins appropriated Roman symbolism of imperial power. This borrowed imagery comes into use after contact with Caesar (Creighton, 2002). Latin and Roman imagery on coins was a statement directed to other Britons as a means of communicating authority (Creighton, 2002). Client kings adopted the word Rex to show the legitimacy of their kingship under Rome (Creighton, 2002).

\section{The Contemporary Context of the Roman Histories and Imperial Propaganda}

The flawed representation of the Britons generally creates the understanding that written testimony from this period is not sacrosanct. Applying the same treatment to Boudica's motivations raises similar issues in knowing her as a historical figure. In addition to Tacitus's (ca. 56-20 C.E./2014) emotional justification for Boudica's revolt, Dio (ca. 230-235/1925) gives an alternative more pragmatic reason for Boudica's revolt in Book LXII of the Annals:

An excuse for the war was found in the confiscation of sums of money that Claudius had given to the foremost Britons; for these sums, as Decianus Catus, the procurator of the island, maintained, were to be paid back (62.2).

Tacitus's and Dio's accounts are problematic as neither author was truly a contemporary of the historical events. Tacitus was only a child in $61 \mathrm{CE}$, and Dio was born a hundred years later. Neither produced a first-hand account, and it must be assumed that their motive for writing was not to provide an objective account. Their work should be read as a reflection of Roman attitudes and political agendas rather than presenting factual narratives. Their writings are received information and not the firsthand experiences of Caesar's contemporaries. Regardless, they underpin subsequent depictions of Boudica. Tacitus's account is narratively more satisfying than Dio's version but not necessarily any more accurate. Much of the mythology of Boudica's revolt, including themes of inheritance and identity, come from Tacitus's emotionally evocative account (ca. 56-120C.E./2014).

The issue of inheritance in Tacitus's story of Boudica seems radically opposed to the legal status of widows and the Roman attitude toward wills. The Roman widow was relatively privileged in the empire. Any property a woman's father gifted a couple upon marriage legally belonged to the wife. While a husband may be entrusted to care for this property during life, the woman retained ownership if she were the surviving spouse. A woman who outlived both her father and husband was legally autonomous (Treggiari, 1991). The nuanced legal status of women after the death of male relatives mirrors the intricacies of inheritance law. Roman obsession with wills was constant throughout the history of the Empire (Chapman, 1991). Romans believed that it was a duty to fulfill the content of a will if the contents of the will were lawful. The Romans accepted the legality of foreign wills, including those written in other languages (Chapman, 1991).

Prasutagus making his daughters his heirs is not controversial in Roman law. Chapman (1991) states that while sons were favoured, it was custom to leave a share of one's estate to one's daughter. Further, if a man had only daughters, the estate would be divided between them. The Lex Voconia restricted some women from inheriting, but those cases were the exception. Per Chapman (1991), the claim that the Romans prohibited all women from property ownership is unsubstantiated and easily disproven.

Prasutagus's choice to divide his estate between the emperor and his daughter was not unique either. The Romans did occasionally name an extraneus (outsider) as coheir. Chapman (1991) writes, 
The emperor also appears as a coheir, but that was under exceptional circumstances, and even the conventional bad emperor would hesitate to accept where children survived. ( $p$. 112)

The emperor in $61 \mathrm{CE}$ was Nero Claudius Caesar Augustus Germanicus (Nero). The historian Suetonius Tranquillus (ca. 69-122 C.E./1997) claims that Nero was considering abandoning Britain as the distance made governing the province tedious, and the inhabitants were troublesome. The emperor Nero is not held in high regard, but it seems unlikely he would have ordered the governor Suetonius Paulinus to usurp the heirs of a client king if he were considering abandoning the province entirely (Suetonius Tranquillus, ca. 69-122 C.E./1997).

Tacitus's works are well known to exaggerate the danger of female leaders and often draw upon the anxieties within the Roman psyche to justify imperial atrocities (L'Hoir 1994). The inconsistency between inheritance laws and Tacitus's account shows the degree to which ideology and propaganda hide in historical works. Although he was born a hundred years after Boudica's revolt, Dio's account is more credible when compared to other sources of evidence. The claim that local officials would take advantage of an opportunity to collect outstanding debts seems plausible, especially in the context of Nero's hesitation to keep Britain under Roman authority (Suetonius Tranquillus, ca. 69-122 C.E./1997). Legal texts provide a concrete testament of social structures in a particular period. The narratives surrounding Boudica's revolt are not consistent with the legal status of women and wills in the Roman empire. The inconsistencies obscure the Iceni Queen as a historical figure, but illuminate how histories can reveal facts about their contemporary period. These historical texts show the collective ideology of a people rather than the singular bias of one author. Comparing Dio's and Tacitus's works to one another and to other primary sources offers an example of how to control for the historian's contemporary ideology.

\section{The Power of Propaganda on Authorial Intent and the Reception of Historical Figures}

The rape of Boudica's daughters is the most poignant motivation Tacitus gives for the revolt. Within the Roman empire, rape was both a physical act and a literary device. Rape was treated with nuance. Rome's founding mythology includes two rape stories- the rape of the Sabine women and the rape of Rhea Silva. Nguyen (2006) states that the role of rape stories in the foundation myths of Rome created an ideological connection between rape and political power. Romans placed an emphasis on female sexual integrity. The social effects of rape were a secondary punishment. Nguyen (2006) writes, "Instead of being seen as victims, raped women were seen as sources of embarrassment to their husbands and fathers" (p. 83). Forced sexual intercourse was only considered a crime when it was done to Roman citizens. While soldiers faced penalties if they committed rape during peacetime, rape was the norm during war (Nguyen, 2006). It is not possible to know the degree of sexual violence experienced by Boudica's daughters. What is known is that the Romans used rape as a narrative tool to explain power.

The Romans used Boudica's gender as a propagandistic theme. Rome had a habit of turning mythologized queens into villains (James \& Dillon, 2012); for example, both Dido and Cleopatra are central in stories of Roman advancement. In the Aeneid, Virgil writes that Dido's guilt is found in her misrepresenting herself as being married to Aeneas and in her inability to control her passions. This guilt makes her suicide just (James \& Dillon, 2012). Cleopatra receives similar scorn in her relationships with Caesar and Marc Anthony and is referred to as the meretrix regina- 
whore queen (James \& Dillon, 2012). Tacitus continues this treatment of prominent women with Boudica, who is presented as the Briton dux femina-female leader. Dux femina is derisive as it implies that a woman has usurped the authority of a man (Gillespie, 2018), and the presence of a dux femina implied male subjugation under a matriarchy (James \& Dillon, 2012). Seen through Roman ideology, this idea of male subjugation was a perversion and contrary to civilized society. The elevation of queens depicted a divided "us and them" that reinforced the ideology of Roman supremacy (Gillespie, 2018). This is particularly true in the depiction of Boudica, as her identity as a barbarian reinforced the us/them division in propaganda (James \& Dillon, 2012).

The propagandistic use of rape is present in the stories of Rome's foundation (Nguyen, 2006). The Romans considered themselves to be the perpetrators. The metaphorical implications of placing yourself as perpetrator offers an external and internal message (Evans, 1985). Foreigners received this as a declaration of authority in which Rome's might validated imperial dominance. Citizens of Rome received an internal message from rape allegories: Power legitimizes all (Evans, 1985). The defeat of Boudica in the context of the rape metaphor shows the extent to which Rome challenged would not result in Rome defeated.

Ultimately, the tragedy of Boudica illustrated the right of Roman power to dominate. To modern sensibilities, the horrors of Roman domination are abhorrent. To the Romans they were proof of their superiority and right to subjugate conquered peoples. The ideological scaffolding of $19^{\text {th }}$ century British nationalism was much more complicated and subtle. Boudica became an intricately faceted historical figure in its service (Vance, 2000).

The amateur antiquarian methods of $18^{\text {th }}$-century investigations of the classical past gave way to a more systematic approach in the $19^{\text {th }}$ century. The discipline of classics in universities revised methodological practices to use an empirical, scientific approach (Rommel, 2001). These shifts in the study of classics and the zeitgeist of late $19^{\text {th }}$-century Britain created fertile ground for Boudica's re-emergence (Vandrei, 2018). The combination of romanticism, colonialism, and a female monarch created an appetite for a figure who was wild, noble, feminine, and duty-bound. Nineteenth century British depictions of Boudica were more openly artistic than the Roman treatment of Boudica (Steyn, 2019). However, these works presented themselves as inspired depictions of Britain's true ancestry (Vandrei, 2018). Published in 1901, Lord Alfred Tennyson's poem BOÄDICEA draws from the Roman accounts for Boudica's battle speech to her troops. Tennyson (1901) writes,

'Hear Icenian, Catieuchlanian, hear Coritanian, Trinobant!

While I roved about the forest, long and bitterly meditating,

There I heard them in the darkness, at the mystical ceremony,

Loosely robed in flying raiment, sang the terrible prophetesses (Lines 34-37)

In using the historical names of Celtic tribes and Boudica's Latinized name as the title of the poem, Tennyson is borrowing the accepted historicity of the Roman sources and brings the reader back to the first century $\mathrm{CE}$. Going further to immerse the reader in the period, Tennyson writes BOÄDICEA in a meter designed to emulate the Roman poet Catullus (Steyn, 2019). Tennyson's meter shifts throughout the poem. BOÄDICEA starts and ends with a more structured meter that is familiar to his contemporary audience. By bookending the poem in this way, Tennyson allows the frenzied meter in the middle of the poem to stand out as foreign and chaotic and allows the reader to experience the febrile anxiety of battle (Lovelace, 2004). In addition to the allusion to Catullus, Tennyson's use of meter imitates the interchange of narrative and dialogue common to Roman historians. The combination of these literary devices presents the poem as if it 
were a primary historical source. BOÄDICEA is a poem about Britain's place in the world. Tennyson (1901) writes,

Thine the North and thine the South and thine the battle-thunder of God.

So they chanted: how shall Britain light upon auguries happier?

So they chanted in the darkness, and there cometh a victory now. (Lines 44-46)

Here, Tennyson shows that the $19^{\text {th }}$-century British audience should identify with Boudica rather than with the Romans. The claim of ownership over cardinal directions reveals a key component of British imperial ideology (Bell, 2006). Nineteenth century British identity expanded beyond the concept of an insular island race. Queen Victoria's contemporary depictions emphasised her position as empress. The conscious choice to link Victoria and Boudica was part of an imperial, propagandistic program. Just as Victoria took on the symbolic role as mother of the British, Britain became the motherland of the wider empire (Bell, 2006). The familial metaphor compelled the subjugated to be "good Christian imperial subjects" (Potter, 2019). Thou shalt honour thy father and thy motherland.

Tennyson would have been aware that Britons of the first century CE were pagans. His reference to God in the singular is intentional. The monotheistic evocation distances the reader/hearer from the pagan practices of the Iceni. In conforming to dominant, $19^{\text {th }}$-century British religious belief, the Christian reader more readily identifies with ancient Britons. British exposure to polytheistic practices expanded through colonialism and reinforced the monotheistic/polytheistic divide (Ganguly, 2017). Maintaining the ideological position of colonization as a civilizing mission relied on historical anachronisms in imperial propaganda (Leutzsch, 2019). If imperial propaganda was to function, the pagan barbarian would have to be obscured (Bell, 2006).

Tennyson's BOÄDICEA responds to a shift in the late $19^{\text {th }}$ and early $20^{\text {th }}$ centuries. The first cracks in the empire emerged at this time. Political discourse of the period sensed that the golden age was waning (Bell, 2006). The slogan "the sun never sets on the British empire" most obviously refers to the territorial expanse of the empire, but there is also a temporal statement. The division of day and night are fundamental in measuring time. The metaphor of the empire in perpetual day presents an eternal empire (Potter, 2019). Tennyson draws upon an existing cultural understanding of this imagery in his poem (Lovelace, 2004). He declaims an ideological call to action by invoking imagery of sunrises and sunsets with descriptions of light, dark, and motion. This departs from depictions of the empire existing in an eternal day. Tennyson makes an emotional connection with the fear of imperial decline by representing the Britons in darkness. Tennyson transitions this ideological fear into a propagandistic imperative in referencing a "coming victory." This use of day and night imagery reflects the attitude that the British Empire had toward the future (Vance, 2000). A frequent theme in Tennyson's work is the propagandistic message that if the British remained true to their ancient heritage, then the empire could overcome all challenges (Rosen, 2016).

Between 1853 and 1885, Thomas Thornycroft produced a bronze sculpture of Boadicea and Her Daughters. In 1898, the statue was installed on Westminster bridge and placed watching over the Houses of Parliament (Vandrei, 2014). Boadicea and Her Daughters is often considered an example of romantic historicism. The figures are idealised with equal parts feminine and virile. The clothing gives the impression of the classical world but is inaccurately stylised (Vandrei, 2014). Thornycroft's sculpture attempts to distill the essence of the nation that Boudica came from. The sculpture was received differently in Victorian Britain: Boadicea and Her Daughters was

Boadicea and Her Daughters by Thomas Thornycroft, Westminster Bridge, London, 1853-1885 CE, Image

Source: Commons Wikimedia Marcus Cyron. https://commons.wikimedia.org/wiki/File:Boudicca_Statue Westminster Bridge, London (7269525940).jpg 
interpreted to represent the balance between the power of the sovereign and the innate nurturing and feminine qualities of women (Vandrei, 2014). Other interpretations claimed the statue represented British exceptionalism and the willingness of Britain to fight for its cultural identity (Vandrei, 2014).

As stated, propaganda is the implicit use of shared cultural symbolism to manipulate the ideology of the individual. Through making the implicit meaning of propaganda explicit, the motivations and desires of the political elite become obvious (Laswell, 1927). Visual language plays a central role inconstructing national narratives (Hebel \& Wagner, 2011), and the $19^{\text {th }}$ century representation of Boudica fits the definition of propaganda. So too do the accounts given by the Romans. Themes of gender, sexual violence, nationality, and authority are prominent in both the British and Roman versions of Boudica.

The British adoption of Boudica is partly a product of the symbolic link that Britain felt with the Roman Empire (Vance, 2000). It is a peculiar choice to iconize the legendary enemy of the empire with which you associate yourself. However, there were additional reasons for the British elevation of Boudica. Female monarchs have been an exception in the British monarchy. During Queen Victoria's reign, her gender raised two issues in relation to the symbolic representation of her power. The first was the lack of suitable previous female monarchs from which to choose. A key tool of propaganda is the act of transfer, in which the attributes of a historical figure are adopted by the propagandist (Lee \& Lee, 1995). For propaganda to be successful, this historical comparison must be controllable. The ability to control the historical figure requires distance between the said figure and the propogandist (Leutzch, 2019). The historical documentation for previous British queens is extensive, and the historical distance too close. Thus, previous British queens were not serviceable symbols for Queen Victoria's reign. Boudica was uniquely situated as a vaguely known but scarcely documented figure (Vandrei, 2014). This ambiguity was ideal to allow the creation of nationalist iconography that linked the ancient past to the British Empire (Aldhouse-Green, 2006). Boudica was transformed into Britannia - a victorious female warrior dressed in a vaguely classical style, carrying a trident and shield decorated with the Union flag. She is often surrounded by clouds in a sort of apotheosis: the mother-goddess of the Empire.

Queen Victoria was caught between the societal expectations of women and the ultimate authority of the sovereign. Boudica could be used to resolve this problem. Tacitus (ca. 56-120 C.E./2014) presents Boudica as an exceptional queen:

It was customary, she knew, with Britons to fight under female captaincy; but now she was avenging, not, as a queen of glorious ancestry, her ravished realm and power, but, as a woman of the people, her liberty lost, her body tortured by the lash, the tarnished honour of her daughters. (14.35)

This account allows Boudica to be represented as a dutiful British monarch, defender of her people, and a nurturing mother, concerned for the fate of her daughters. Here Boudica's actions are not self-interested or ambitious. Instead, Boudica's actions show her to be the ultimate mother- the mother of the nation (Mikalachki, 1998). Such a woman sacrifices herself for her people.

Sexual violence is an uncomfortably common presence in empire, both as metaphor and action and enforces the symbolic power of Boudica's womanhood. Nineteenth century Britain responded to the rape of Boudica's daughters as metaphorical. Andrew Goatly (2006) writes that metaphor is a tool of ideology, and sex and violence are symbolically linked through metaphorical language. The victim of the metaphorical rape has lost a struggle for power and thus their 
autonomy. Rape metaphors are common within colonialist structures, although they are normally used by the subjugated group to express this position (Sharpe, 1993). At the height of empire in the $19^{\text {th }}$ century, Britain could hardly claim to be a subjugated nation. However, the appropriation of the colonial rape metaphor served a propagandistic aim. The rape of Boudica's daughters shows the lack of autonomy that Britain once had (Steyn, 2019). In relation to the Romano-British, the British empire promotes the idea of a national exceptionalism and shows the dominance of the British empire to be the result of the uniqueness of the British character (Sharpe, 1993).

Themes of nationalism and authority work together. The $19^{\text {th }}$-century British treatment of Boudica imposed British values onto the story to create a wellspring of national identity. Another prominent figure in the iconography of British nationalism is Britannia (Bhreathnach-Lynch \& Cusack, 2017). Dating to classical antiquity, Britannia was depicted as the personification of Britain (Aldhouse-Green, 2012). Boudica and Britannia are separate figures, but their histories as British icons have been woven together. These two foundational figures coalesced during the golden age of the British empire, conflating Boudica's and Britannia's attributes to create a new iconography to serve $19^{\text {th }}$-century objectives (Steyn, 2019). The classical depiction of Britannia presents her as a larger-than-life figure with allegorical references to classical divinities. She is distanced from individual Britons and often appears elevated above them (Bhreathnach-Lynch \& Cusack, 2017). In contrast to Britannia's divine aloofness, Boudica is depicted as a virtuous woman leading her people (Steyn, 2019).

Examples of the Boudica/Britannia conflation occur as early as 1803. In a print by William Nelson Gardiner, a female figure in classical dress with plumed helmet, trident, and shield is seen behind and above a group of officers, soldiers, businessmen, a woman seated with a baby, and a small boy defiantly holding up his arms. To the right of this group there is a cannon facing the sea. Across the sea is France. The print is titled "The Freeman's Oath." The figure in the Freeman's Oath is given as Britannia but the iconographical influence of Boudica is clear. While she is above the crowd, the figure is not separated from them. She does not take the position of divine guardian. Rather, the figure is leading the crowd into battle as would a warrior queen. The presence of children also draws upon Boudica's role as a sacrificial mother.

The Freeman's Oath from [Loyal and patriotic handbills, songs, addresses, etc. on the threatened invasion of Great Britain by Buonaparte.] by William Nelson Gardiner, published est. 1803 London, housed in the British Library. https://www.bl.uk/collection-items/thefreemans-oath-from-a-collection-of-material-relatingto-the-fear-of-a-french-invasion

The Freeman's Oath responds to Napoleonic expansion and British anxiety related to a possible invasion by the French. Napoleonic iconography was rooted in classical Roman imagery 
(Dandelet, 2014). Boudica/Britannia is an icon of a free, elevated, and exceptional nation, and an embodiment of sacrifice, rebellion, and resistance. This icon sent a powerful message. Britons, as far back as Boudica, had resisted oppression and earned their freedom. The message contained in the iconography of Boudica/Britannia changed throughout the $19^{\text {th }}$ century (Steyn, 2019). Using this imagery to present the British as uniquely free amongst the peoples of the earth gave the imperial project a perceived moral duty to export this freedom throughout the empire (Coutu, 2006). Thus, the Boudica/Britannia conflation ideologically underpins the propaganda of the British colonial mandate.

\section{Boudica in Review and Conclusions}

With polemical Roman writings as the only primary evidence of Boudica's existence, it seems that the "true" Boudica will never be known. At best, the writings of Cassius Dio and Tacitus are historiographically reductive. Archaeological advances will continue to teach us much about Romano-British society, but archaeology usually presents a big picture and rarely offers detail about historical events and individuals. Thus, archaeology is better suited to verifying claims rather than establishing a narrative history. The differing depictions of Boudica shows the extent to which historians are impacted by the ideologies of their contemporary periods. Explicitly acknowledging the limitations of scientific methodology in historiography is important in the current climate of ideological criticism of academic work. Acknowledging the inseverable bond between an author and their period allows the work to be used as a lens into the zeitgeist of that period. What we are left with is an opportunity to see how two vast empires, separated by over a millennium, used Boudica to promote their propagandistic program, and the ways in which ideology and propaganda have been ever present in the construction of history. 


\section{References}

Abulaf, D. (2021, September 10). We can never surrender to the woke witchhunt against our island story. PressReader.com - Digital Newspaper \& Magazine subscriptions. Retrieved September 19, 2021, from https://www.pressreader.com/uk/dailymail/20210910/281784222211657

Aldhouse-Green, M. J. (2006). Boudica Britannia: Rebel, war-leader and queen (1st ed.). Pearson Longman.

Aldhouse-Green, M. (2012). 'Singing stones': Contexting body-language in Romano-British iconography. Britannia, 43, 115-134. https://doi.org/10.1017/S0068113X12000190

Bell, D. (2006). The idea of a patriot queen? The monarchy, the constitution, and the iconographic order of greater Britain, 1860-1900. Journal of Imperial and Commonwealth History, 34(1), 3-22. https://doi.org/10.1080/03086530500411225

Bhreathnach-Lynch, S., \& Cusack, T. (2017). Art, nation and gender: Ethnic landscapes, myths and mother-figures (1st ed.). Taylor and Francis.

Breisach, E. (2007). Historiography: Ancient, medieval, \& modern (3rd ed.). University of Chicago Press.

Caesar. (1917). The Gallic war (H. J. Edwards, Trans). Harvard University Press. (Original work published ca. 54-49 B.C.E.)

Chapman, E. (1991). Final judgments: Duty and emotion in Roman wills. University of California Press.

Cicero. (2002). Letters to Quintus and Brutus; Letter fragments; Letter to Octavian; Invectives; Handbook of electioneering (D. R. Shackleton Bailey, Trans.). Harvard University Press. (Original work published ca. 50-43 B.C.E.)

Coutu, J. M. (2006). Persuasion and propaganda: Monuments and the eighteenthcentury British empire. McGill-Queen's University Press.

Creighton, J. (2000). Coins and power in late Iron Age Britain. Cambridge University Press.

Dandelet, T. J. (2014). The renaissance of empire in early modern Europe. Cambridge University Press.

Dio, Cassius. (1925). Roman history (H.B. Foster, Trans.). Harvard University Press. (Original work published ca. $230-235$ C.E.) 
Evans, J. D. (1985). The legends of early Rome used as political propaganda in the Roman republican and Augustan periods (Numismatics, Painting, Sculpture) (Publication No. AAI8523409) [Doctoral dissertation, University of Pennsylvania]. ProQuest Dissertations \& theses Global. https://repository.upenn.edu/dissertations/AAI8523409

Ganguly, S. (2017). Idolatry: Concept and metaphor in colonial representations of India. South Asian History and Culture, 8(1), 19-91.

Gillespie, C. C. (2018). Boudica: Warrior woman of Roman Britain. Oxford University Press.

Goatly, A. (2006). "Ideology and metaphor.” English Today 22(3), 25-39. doi:10.1017/S0266078406003051.

Gonzalez, S. S., \& Gugliemi, A. (Eds.). (2017). Romans and barbarians beyond the frontiers: Archaeology, ideology and identities in the north. Oxbow Books.

Gunderson, E. (2009). Declamation, paternity, and roman identity: Authority and the rhetorical self. Cambridge University Press. https://doi.org/10.1017/CBO9780511482212

Hebel, U. J., \& Wagner, C. (2011). Pictorial cultures and political iconographies: Approaches, perspectives, case studies from Europe and America (1. Aufl. ed.). Walter de Gruyter.

Herman, E. S., \& Chomsky, N. (1988). Manufacturing consent: The political economy of the mass media (1st ed.). Pantheon Books.

Horace. (2003). The odes (A.S. Kilne, Trans.). Poetry in translation. https://www.poetryintranslation.com/PITBR/Latin/HoraceOdesBkIII.php\#anchor_Toc40 263849 (Original work published ca. 23 B.C.E.)

James, S. L., \& Dillon, S. (2012). A companion to women in the ancient world. Wiley-Blackwell.

Joy, J. (2015). Connections and separation? Narratives of Iron Age art in Britain and its relationship with the continent. In H. Anderson-Whymark, D. Garrow \& F. Sturt (Eds.), Continental connections: Exploring cross-channel relationships from the Mesolithic to the Iron Age (pp. 145-165). Oxbow Books.

Lasswell, H. D. (1927). The theory of political propaganda. The American Political Science Review, 21(3), 627-631. https://doi.org/10.2307/1945515

Lee, A. M., \& Lee, E. B. (1995). The iconography of propaganda analysis. ETC: A Review of General Semantics, 52(1), 13-17.

Leutzsch, A., (2019). Historical parallels, commemoration and icons. Routledge.

L'hoir, F. S. (1994). Tacitus and women's usurpation of power. The Classical World, 88(1), 


\section{5-25. https://doi.org/10.2307/4351613}

Lovelace, T. J. (2004). The artistry and tradition of Tennyson's battle poetry. Routledge.

Masters, R. D. (1979). On the ubiquity of ideology in modern societies. Cahiers Vilfredo Pareto, 17(46), 159-172.

Mattingly, D. (2006) An imperial possession: Britain in the Roman empire. Penguin Books.

Mccullagh, C. B. (2000). Bias in historical description, interpretation, and explanation. History and Theory, 39(1), 39-66. https://doi.org/10.1111/0018-2656.00112

Mikalachki, J. (1998). The legacy of Boadicea: Gender and nation in early modern England. Routledge.

Nguyen, N. L. (2006). Roman rape: An overview of Roman rape laws from the republican period to Justinian's reign. Michigan Journal of Gender \& Law, 13(1), 75.

Perring, D. (2008). The Roman house in Britain. Routledge. https://doi.org/10.4324/9780203463857

Potter, M. C. (2019). British art for Australia, 1860-1953: The acquisition of artworks from the United Kingdom by Australian national galleries. Routledge.

Rohland, E., Epple, A., Flüchter, A., \& Kramer, K. (2021). Contact, conquest and colonization: How practices of comparing shaped empires and colonialism around the world. Routledge.

Rommel, G. (2001). The cradle of titans: Classical philology in greifswald and its history from 1820. Illinois Classical Studies, 26, 169-178.

Rosen, J. (2016). Julia Margaret Cameron's 'fancy subjects' - Photographic allegories of Victorian identity and empire. Manchester University Press.

Seliger, M. (2019). Ideology and politics. Routledge.

Seneca, L. A. (2014). Satyricon. Apocolocyntosis (P. Arbiter, Trans.). Harvard University Press. (Original work published ca. 54 C.E.)

Sharpe, J. (1993). Allegories of empire: The figure of woman in the colonial text. University of Minnesota Press.

Shotter, D. (2012). Roman Britain. Taylor and Francis. https://doi.org/10.4324/9780203981900 
Strabo. (1917). The geography of Strabo: Geography. English and Greek (H. L. Jones, Trans.). Heinemann. (Original work published ca. 7 B.C.E-23 C.E.)

Steyn, M. C. (2019). Iceni to iconic: Literary, political and ideological transformations of Boudica through time. Literator, 40(1), 1-12. https://doi.org/10.4102/lit.v40i1.1474

Suetonius, G. T. (1997). Suetonius (J. C. Rolfe, Trans.). Harvard University Press. (Original work published ca. 69-122 CE.)

Tacitus, C. (2014). Tacitus (E.H. Warmington, Trans.). Harvard University Press. (Original work published ca. 56-120 C.E.)

Taylor, P. M. (1995). Munitions of the mind: A history of propaganda from the ancient world to the present era (New ed.). Manchester University Press.

Tennyson, A. (1901). BÖ̈DICEA.

Treggiari, S. (1991). Roman marriage: Iusti coniuges from the time of Cicero to the time of Ulpian. Clarendon Press.

Vance, N. (2000). Imperial Rome and Britain's language of empire 1600-1837. History of European Ideas, 26(3), 211-224. https://doi.org/10.1016/S0191-6599(01)00020-1

Vandrei, M. (2014). A Victorian invention? Thomas Thornycroft's 'Boadicea Group' and the idea of historical culture in Britain. The Historical Journal, 57(2), 485508. https://doi.org/10.1017/S0018246X14000119

Vandrei, M. (2018). Queen Boudica and historical culture in Britain: An image of truth (First ed.). Oxford University Press.

Webster, G. (1980). The Roman invasion of Britain. Barnes \& Noble.

Webster, G. (1999). Boudica: The British revolt against Rome AD 60 (Rev. ed.). Routledge.

Williams, R. A., \& de Veslud, C. L. (2019). Boom and bust in bronze age Britain: Major copper production from the great Orme mine and European trade, c. 1600-1400 BC. Antiquity, 93(371), 1178-1196. https://doi.org/10.15184/aqy.2019.130 